\title{
Face and trust: A semiotic inquiry into influencers, money, and amygdala
}

\author{
Kristian Bankov ${ }^{1}$
}

\begin{abstract}
After the cultural explosion of Web 2.0, digital culture reveals an apparently semiotic paradox associated with the incredibly widespread use of images of faces, while at the same time the reason to trust in the authenticity of these faces is constantly declining. This is because graphic technology has made the sophisticated manipulation of images both possible and easy. After a review of the existing semiotic models and considerations of trust, I am proposing a new approach which emphasizes the value-generating properties of trust by analogy with the money sign, seen as "trust inscribed". Research from the neurosciences supports the hypothesis that the trustworthiness of the face is judged pre-reflexively and primordially. This, therefore, means that a trustworthy face is a premise for more successful communication than an untrustworthy one, notwithstanding the object of discussion and the cultural context. An example concerning social media influencers serves to show that in the internet-dominated globalizing culture, trustworthy faces are a multipurpose communicative asset that makes a difference.
\end{abstract}

Keywords: face; trust; semiotics; influencers; economic value

\section{Introduction}

After the cultural explosion of Web 2.0, digital culture reveals an apparently semiotic paradox associated with the widespread use of images of faces, while at the same time the reason to trust in the authenticity of these faces is constantly declining. This is because graphic technology has made extremely sophisticated manipulation of images possible. As Massimo Leone (2019: 20) puts it, "pictures of the face are now extremely believable and extremely untrustworthy at the same time". Roland Barthes saw the semiotic nature of photography in its ontological relation with reality (Barthes 1981: 85), but today the trend is increasingly more

\footnotetext{
1 Sichuan University/New Bulgarian University, Sofia, Bulgaria; e-mail: kbankov@nbu.bg.
} 
connected with the modification of the faces we can see on screens and their value deriving from differences with their real offline referent. Here we are talking about a whole prosperous industry, emblematic of all areas of our digital everyday life.

There was much discussion surrounding the Academy Awards 2020 in Bulgaria. A special FX company run by two of our compatriots received an award in the category of Special Effects. One of the most complex things this company does is realistic animation of the faces of celebrities from the past and introducing them into new plots in modern productions. Thus, the last episode of Season 2 of The Mandalorian (2020) featured an appearance of the legendary Luke Skywalker at a visible age of about 30, interpreted by the no less legendary actor Mark Hamill. The amazement of the savvy spectator was based on the fact that the actor was approaching 70 in the year of filming. Such manipulations of faces have been created for at least 20 years now, but today the phenomenon is becoming a significant part of popular culture. With the same technology, the UK television network Channel 4 created a fictional Christmas speech by Queen Elizabeth II to the astonishment of the television audience. The main topic of the speech was the trust in what is seen in media, as well as new technologies allowing reality manipulation. It has become the norm not to accept compromising videos involving famous politicians and businessmen until experts have proven beyond doubt that no special effects have been used. It has become easy to modify lip movements in a completely realistic way in a video of a famous person, and to attribute to him/her the pronouncement of words that s/he has never uttered. As a result of such, and many other, abuses, there is already a branch in cybersecurity known as 'Faceforensics.' In 2019 the state of California ratified Bill AB-602 which bans the use of human image synthesis technologies to make fake pornography without the consent of the people represented, and Bill AB-730 which prohibits distribution of manipulated videos of a political candidate within 60 days of an election.

More and more mobile apps are creating value by manipulating selfies or other photographs of users' faces. These are classic beautifying techniques such as erasing wrinkles and skin imperfections, enlarging the eyes, optimizing the face oval and the shape of the jaw, etc. The product of these selfie manipulations is most often used for profile pictures or simple posts on social media. The aim is to obtain approval/recognition for the referent of the manipulation, not so much for the complex semiotic act of communication. Strangely, manipulated

2 Rossler, Andreas; Cozzolino, Davide; Verdoliva, Luisa; Reiss, Christian; Thies, Justus; Nießner, Matthias 2018. FaceForensics: A-large-scale video dataset for forgery detection in human faces. Available at: https://arxiv.org/pdf/1803.09179.pdf; last accessed on 30 January 2021. 
face and body photos are also widely used in dating applications such as Tinder, although in theory their success is based on the trust that what we see in the photos corresponds to what we will see at a real-life meeting. We can imagine that the manipulated improvements actually stimulate the imagination and condition the perception when the time arrives for a face-to-face meeting, which puts consumers in a win-win situation.

Social media apps (such as Reface) which allow the user to put his or her face in the place of that of a celebrity in videos with cult scenes from the cinema or videos of a virtuoso performance are gaining huge popularity. Video manipulations in the opposite direction are also becoming popular - celebrity faces replace the faces of unknown participants in pornography, misleading naive viewers to think that they are actually watching celebrity porn (Alexandrou, Maras 2018).

Even "serious" online conferencing platforms such as Zoom have recently developed applications that manipulate the appearance of communicators in real time. Rossler et al. summarize the problem: "The ability to effortlessly create visually plausible editing of faces in videos has the potential to severely undermine trust in any form of digital communication" (see fn 2).

\section{"This face does not exist" controversy}

The essence of the problem transpires as a result of the debate around the application of AI technology for deep learning Generative Adversarial Network (GAN). In the context of the Deepfake productions the role of the face is central and considerable research is being conducted on the topic. Shen et al. 2019 as well as Tinsley, Czajka and Flynn ${ }^{3}$ provide a good overview of the known facts and the research literature on the relevance of the problem. For the sceptics:

[i]n the age of fake news and alternative facts, the risks and dangers associated with ill-intentioned individuals or groups easily routing forged visual information through computer and social networks to deceive, cause emotional distress, or to purposefully influence opinions, attitudes, and actions have never been more severe. (Shen et al. 2019: 23)

GAN technology probably would have remained popular only within the IT and design professionals' environment, if it were not for its application on the human

3 Tinsley, Patrick; Czajka, Adam; Flynn, Patrick 2020. This face does not exist... but it might be yours! Identity leakage in generative models. Pre-print of a paper to be presented at WACV 2021. https://arxiv.org/pdf/2101.05084.pdf (last accessed on 20 February 2021). 
face. The way it is applied to the face illustrates how it can be applied to any other visual data. GAN allows for photorealistic synthesis of digital images of human faces that does not correspond to any existing human. They can be seen on the website https://thispersondoesnotexist.com/ and the effect on the viewer is striking: it breaks our ontological relation with reality as no other type of images does. As we shall see, there is a primordial and pre-reflexive moment in the perception of the face which overwhelms the consciously perceived statement that such a face cannot exist in the real world. I wonder how Levinas would have commented on such "otherwise than being" of the face. In the proposed framework this is a semiotic paradox which would not have been possible before an advanced phase of the digital technologies.

\section{Trust in semiotics}

"In semiotics we trust" may be the credo of many among us who base our careers as researchers on the science of signs, but very few have taken a theoretical interest in that basic notion. In this part of the article, I firstly list the major contributions of semiotics of trust, and then try to position the problem of trust in the main semiotic models, in an attempt to explain the weak interest.

The classic author who comes closest to the concept of trust is Greimas. The Semiotics of Passions (1991), written together with Jacques Fontanille, sees trust as an ingredient in some of the well-known passions, especially jealousy, but also stinginess. There is a mini semiotic square (see Fig. 1), dedicated to a modal analysis of trust (confiance in French), which explores semantic subtleties of the French language, untranslatable to other languages (Greimas, Fontanille 1991: 218):

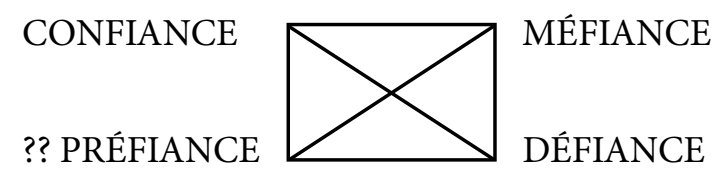

Figure 1. Semiotic square of trust/distrust.

The analysis is exciting and could be developed into a stand-alone model, but the framework and context are entirely textual and literary. In these, trust is reduced to a logical operator in the modal structure of passions, and although the claim of the overall theory is for a semiotics of human action, it does not exist outside the 
textual world (dictionaries and literary works). In the "real world", according to my framework, degrees of trust reflect the success and capitalization of communicative interactions. Fontanille's student Amir Biglari develops in depth the semiotics of passions in relation to hope, where trust has an even more central role (Biglari 2011). However, once again in this work trust is necessarily immanent to a literary textual structure, using the same literary references, in particular The Man Who Laughs by Victor Hugo.

In his general theory, Greimas "clears" all the methodologically dubious implications of the instance of trust by introducing one of the most ingenious tricks of his theory - replacing the notion of truth with that of truth-saying, or veridiction. According to Eco (2000: 257), "that seems tailor-made to irritate any upholder of a truth-functional semantics, not to mention every supporter of a correspondence theory of truth". Nevertheless, this trick ensures the exceptional internal coherence of the theory. From a potential source of metaphysical torment, the problem of trust is resolved as a fiduciary contract working as a logical binary code - either it exists, or it does not exist. If there is a fiduciary contract, the semiotician can consider the semantic effects of the communicative process according to the canonical generative model, and if there is no such contract, there is no reason for the method to be applied.

Such a construct of the semiotics of trust does not work for the purposes of a study of the role of the face in digital communication, since the intrigue lies more in the intermediate positions and degrees, rather than in the overall presence or absence. We find similar intermediate positions and preconditions for successful semiotics of trust in Eco's textual pragmatics model developed in The Role of the Reader (Eco 1994). This work presents the modelling of a much more dynamic signification process in which, albeit without a direct semiotic modelling of trust, there is an entire dialectic of the relationship between the author and the reader based on, as we shall see, a simulacrum of trust in the sense that the driving force of the interpretive process is the reader's presuppositions, governed by the narrative mechanisms of the plot set by the author. A good author manages to gain the trust of his empirical reader by appropriately inscribing in the text a reader model, which bears encyclopedic competencies similar to the reader's genre and life competences. The author's ally in this endeavour is the process of suspension of disbelief, with which the reader voluntarily abdicates - but only to a certain extent - his or her critical distrust of the narrated facts and events (Eco 1994: 16, 208). In this way, the reader begins to inhabit the possible world of the work imaginatively and switches from their everyday system of expectations to a fictional one, trusting in certain possible confluences of the plot at the expense of others. It is the reader's trust that is the most valuable asset for the author since it is thanks to this that the author 
can create the highly desired twists in the action. These twists show the reader that his/her trust, collaboratively misled by the author, has been projected in the wrong direction. Each twist in the course of the plot is a retelling of the cards on the table and a new round of the game of trust and conjecture.

In Eco's model, the concept of frame plays a central role in explaining the process of the permanent presupposition that drives interpretation (Eco 1994: 21-27). He shapes the notion of 'intertextual frames'. Frames are culturally codified portions of meaningful experience that the author relies on as being available in the readers' encyclopedic competence and used by them to unravel the plot. At the same time, an important direction in the otherwise boundless research of trust also puts the concept of frames at the centre of its theoretical modelling (Lewicki, Brinsfield 2011) and, as we will see in the next section, the analogies are impressive.

Valuable input into the semiotics of trust might have been expected from the cognitive branch of the discipline, but as surprising as this may seem, the global repositories of published research show a marked absence of such work. The story is different with Peirce - as with any other subject imaginable, he has his considerations on the notion of trust as well. Although these are quite marginal in comparison to other notions, they carry a heuristic potential (on the faith-trustperception continuum) to be explored even in the context of the research direction referred to in the following paragraphs. Should the reader want to pursue the inquiry, great systematic review of the notion of trust in Peirce can be found in Pope 2018.

Otherwise, Peirce's concept of abduction has been used to define a new method of examining trust in the context of business organizations (Le Gall, Langley 2015), although this cannot be defined as a semiotic contribution. Similarly, the phrase 'semiotics of trust' is sometimes used in the complex matter of trust in financial markets, but it appears at a superficial metaphorical level, reflecting the need for certain symptoms and signals from stock exchanges to be interpreted in a timely manner for more adequate financial asset management (Bikoula 2011; Swedberg 2010, 2012).

A very original contribution under the label 'Trust in Signs' is offered by Bacharach and Gambetta (2001) who have developed an accomplished model. The context is that of the trust in society in general, and the emphasis falls on the everyday practices of using credit cards, money exchange, touristic situations, games of deception, and the like. The authors define this situation as "relentless semiotic warfare" (Bacharach, Gambetta 2001: 167), but the only theoretical reference they provide is that of the signal theory, while semiotics as a theory is completely absent. The way the action of all signs and strategies of deception is described and modelled is naive, as there is no instance of enunciation, and the signs/signals are conceived as bearers of universal meaning, independent of the 
syntagmatic chain or the pragmatic situation. Yet what is interesting for our inquiry is the part on the signs/signals of identity (Bacharach, Gambetta 2001: 167ff). The authors introduce the term 'Krypta' - the unobservable properties of a person that are his/her trust-warranting features (Bacharach, Gambetta 2001: 177). In this case, the context-independent efficacy of trustworthiness of Krypta is close to the way in which I define the semiotic efficacy of the face, but beyond the description nothing else can be unpacked from this model to develop my proposal, which is focused on digital communications in the post-truth era.

In authors such as Liu and French we find very specific applied models of the semiotics of trust. They are used for operational diagnostics of online services and virtual organizations (French, Liu, Springett 2006) ${ }^{4}$. The joint publication of these authors sets out a detailed methodology for research commissioned with companies conducting business through web platforms in mind. The end product for the clients of such a study is a semiotic trust profile. For this purpose, the most general cultural semiotics approach is used, which, unlike conventional approaches, provides the necessary significance to the socio-cultural world of consumers through cross-cultural analysis (French, Liu, Springett 2006: 177, 180).

Another important contribution offered by these authors is the creation of a model in which the factors generating trust in virtual organizations are graded. This model is called the Semiotic Trust Ladder and it "currently functions as a kind of metamodel, within which VO [virtual organizations] partners can conceptualize e-trust issues within a typical partnership, from its earliest inception to design and implementation"5 (French, Bessis, Maple 2010: 1115).

Although these models are valuable as a practical application of a semiotics of trust, they cannot provide the necessary theoretical basis for the purposes of this study focused on the role of face in trust building in the era of ubiquitous digital image manipulation.

\section{No trust inside the text}

Before proposing certain semiotic reflections on the relationship between face and trust on the Internet, let us elaborate the analogies between the role of trust

4 French, Timothy Stewart; Liu, Kecheng; Springett, Mark 2006. Towards an E-Service Semiotic Trust Framework. In proc. ALOIS 2006, Borås, Sweden; available at http://www.vits. org/uploads/alois2006/french_liu_springett.pdf.

5 French, Timothy Stewart; Bessis, Nik; Maple, Carsten 2010. A high-level semiotic trust agent scoring model for collaborative virtual organisations. 2010 IEEE 24th International Conference on Advanced Information Networking and Applications Workshops. 
in the "inferential walks" in text interpretation and the "inferential walks" in real life, when we are faced with a choice among different hypotheses of action. An influential method for studying trust is one that sees it as the essence of heuristics for decision-making and judgment (Lewicki, Brinsfield 2011, 2015). Here the concept of the frame is at the heart of the theoretical model and may be seen to introduce the theory of trust in purely semiotic terms: "Framing is about making sense of a complex reality and defining it in terms that are meaningful to us" (Lewicki, Brinsfield 2011: 116). Minsky is a common reference for both approaches. Trust is a kind of shortcut in the process of giving meaning to the reality around us and making it practically possible. "People are not accustomed to thinking hard, and are often content to trust a plausible judgment that comes to mind" (Kahneman 2003: 1450). The same thing happens in the mind of a text reader that is left to the delight of the narrative, rather than reading like a detective or an experimental scientist looking for logical inconsistencies and factual errors that can often be found in fascinating stories. Research into trust shows that in real "out-of-text" life, for purely practical reasons people are forced to suspend their disbelief in some weak form just as they are when reading fiction. Concerning textual interpretation, Eco (1994: 17) speaks of intertextual frames which culture and textual experience create to facilitate text's semantic functioning. In "real life" another kind of frames that are ready-made as well, but derive from a different kind of individual and social experience, build the meaning.

However, at this point the main difference between the two semiotic processes appears. A closer look at the most widely accepted definitions of the concept of trust reveals something; e.g. Lewicki and Brinsfield (2011:125) quote Rousseau: "Trust is a psychological state comprising the intention to accept vulnerability based on positive expectations of the intentions or behavior of another" (my emphasis, K. B.). Vulnerability also appears in many other definitions of trust (Lewicki, Brinsfield 2011: 125). However, it is something that is completely missing both in the interpretation of the text from the point of view of textual pragmatics and in the immanentist approach of the generative model. The text is by definition a fixed discourse, given once and for all, and no matter how unusual the inferential walks made by the reader are, he/she risks absolutely nothing given that he/she is ultimately served an identical textual manifestation with an identical structure. There may be a description of trust in the text as a narrative structure or modality, but there is no such psychological state. Vulnerability can only happen in a situation of interactive communication or action. It is one thing to watch with bated breath how James Bond plays with the fate of humanity in a poker game, but another to play poker ourselves and to win or lose a certain amount of money on our choice of hand. There is no trust in the text, because in the semiotic mechanism of its 
semantic actualization there is no instance of decision-making. What we see in the text from a perspective of textual pragmatics is trust by analogy with the extratextual condition of trust. In other words, it is a simulacrum of trust. Accordingly, the theoretical modelling of the existential state of trust in textualism is doomed (see Bankov 2018, 2022).

\section{Face, primordial trustworthiness and self-fulfilling prophesy}

Let us now turn to the field of neuroscience in order to see what ideas from there can enrich our semiotic view of the face-trust relationship. The findings are very encouraging. A fundamental discovery was made in the early 1990s: the AmericanPortuguese neuroscientist Antonio Damasio, when researching patients with brain injuries, located quite clearly an area in the brain where instant and primordial judgements of trust/distrust after seeing a face take place (see Colins 1998). This is the part called the amygdala in the centre of the brain. The conclusion is that these judgements on a level of instantaneity and primordiality are identical with emotional reactions in every perception. At the same time, these reactions have more important consequences than others, since they are more ethically reflexive than these. At the heart of the so-called first impression, there is a kind of capital of trust with longer-lasting consequences. The team of the Bulgarian-American neuroscientist Alexander Todorov conducted experimental research into Damasio's perspective on perceived trust, comparing instantaneous judgment with longerlasting impressions, based on the subjects' deeper familiarity with each other. The results show a strong correlation between the two phases of judgements on trustworthiness, i.e. the validity of the primordial judgment is proved (Todorov, Oosterhof, Baron 2008).

Another team of authors changed the research perspective and experimented on the behavioural effects on the carriers of more or less trustworthy faces themselves (Slepian, Ames 2016). The social adaptation of individuals with varying degrees of trustworthiness in their faces creates behavioural strategies which correspond to and internalize such a degree. In other words, if someone is born with a trustworthy face, for example, babyface (Slepian, Ames 2016: 286), then his/her social behaviour, driven by the need for adequacy to the expectations of others, will be such as to justify the credited trust, while untrustworthy faces self-generate social distrust. To explain the phenomenon, the authors use the term "self-fulfilling prophecies" (Slepian, Ames 2016: 283, 287), as it is used in the psychosocial sciences. For us, this means that the trust capital of the trustworthy face as a social construction has a tendency to be polarized in an objective way. 
Since the dawn of time, petty fraud with abuse at the level of primordial prereflexive trust created by "good" faces has taken place, e.g. many tourist have become the subject of petty abuse by local individuals specializing in this business. The interesting thing here is that the strength of the effect of trust created by the face is such that a person repeatedly falls into the same trap time after time. There are many analogies with theatrical performances. Theatre anthropology defines a pre-expressive level of stage presence that is transversal to all traditions and techniques. It is a prerequisite for a good actor to be convincing on stage for the spectator to believe in his/her role. In everyday life, the face and its level of trustworthiness has the same pre-expressive function (Bankov 2003), which makes the same communicative acts achieve their goal if fulfilled by "good" faces, and fail if fulfilled by "bad" faces. In the normal dynamic of social life, a face's trustworthiness can have a significant impact on life experience, including lifechanging situations (Slepian, Ames 2016: 283). In the case of tourist fraud, the situation is not ordinary, since the contact has no temporal perspective - all we have is a pure form of monetary capitalization of the pre-expressive trustworthiness of the face of the fraudsters. The topic of the relationship between trust and its transformation into monetary value is the subject of the final chapter of the study.

\section{Trust, faces, influencers, and economic value: A research direction}

The approach I propose for the semiotic conceptualization of the relationship between the face and trust in the digital age is just a research direction for a potentially large and challenging research programme. As we shall see shortly, the issue hits the core of a megatrend in global socio-economy, which is why my approach begins from the extremely insightful definition of money which opens a completely new perspective in the modelling of digital culture. This definition states that money is "trust inscribed" (Ferguson 2008: 30).

Over the last four to five years, I have devoted a great deal of research to this type of sign to develop a holistic semiotic perspective in which many of the age-old boundaries between money and non-money have become blurred. In this logic, for example, the explanation for the incredible success of bitcoins as a currency boils down to two fundamental things: trust and adoption (Bankov 2022: 82). The Internet has made possible the emergence of a wide variety of monetary forms, most of which aim at autonomy from the central banking system. This has given rise to time banking, video games currencies, and many other creative forms of measuring and exchanging value through various online platforms. I believe that 
the face with its capacity to be a bearer of primordial and pre-reflexive trust can take a worthy place within this sign logic.

It is no coincidence that this article illustrates my thoughts on the semiotic relation of the face and trust with the figure of the influencer. Certainly, this is not the only manifestation of the relationship studied, but the influencer is an emanation of the cultural changes in the digital age, especially from the phase of social media (Web 2.0). This is a megatrend: the agency Upfluence lists four million professional influencers, and this is the result of only a few years of growth in this field. ${ }^{6}$ We must also take into account all the millions of users who aspire to this status, but have not yet found a way to achieve it, as well as the millions who are de facto influencers, but have not turned it into a profession.

It would be no exaggeration to say that the face is the semiotic device that creates the preconditions for the influence that each influencer has on his/her followers, regardless of the field of interest. When a team from the online magazine Papermag. com dedicated research to unravelling the secret of the success of influencers, they focused their efforts on the influencers' faces. The result of this study is a synthesized image of the faces of the 100 most influential Instagram influencers. Undoubtedly, this face (Fig. 2) well illustrates the hypotheses of neuroscientists about face trustworthiness, although it was achieved by a different methodology. Another scientific study confirms that the key to success is not the attractiveness of the face, but its ability to inspire trust and intimacy (Marôpo, Jorge, Tomaz 2019).

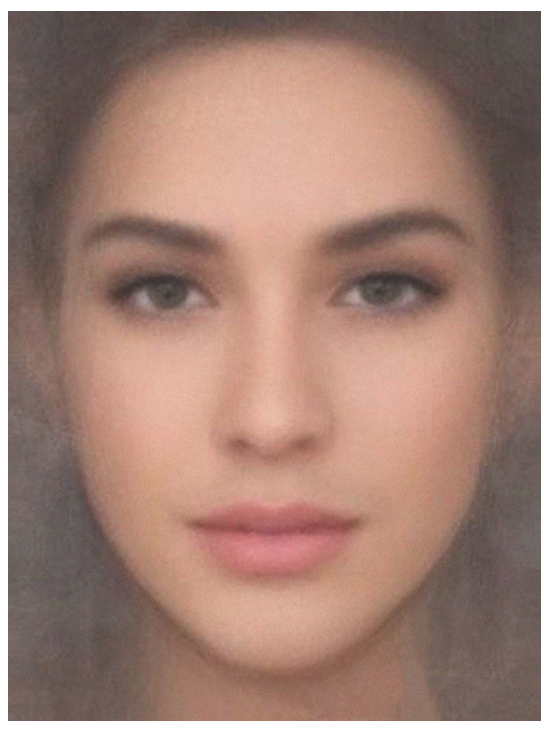

Figure 2. The Ideal Influencer - synthetic face of the 100 top Instagram influencers. (Credits to PAPER Magazine/ PAPERMAG.com.)

6 See https://www.upfluence.com/influencer-profiles (last accessed on 31 January 2021). 
There are influencers who never show their faces. Some techno geeks never appear on the videos, others generate their influence by collecting images or videos of other people and subjects, etc. I could not find reliable statistics in regard to this, but my assumption is that these are minor cases, and the common mainstream influencer is visualized well in front of the camera and speaks to her/his followers.

Other important point is that having a trustworthy face is not enough to become an influencer automatically. My firm belief is that a trustworthy face is a tangible and objectively measurable asset; one that gives indisputable advantages to the owner and creates difficulties for those who lack it. The conditions for the increased value of trustworthy faces are rooted in one of the main consequences of the culture of social media - the total crisis of trust. Some summarize this situation as post-truth, others as post-factual democracy. "Post-truth" even became Word of the Year 2016 of the Oxford Dictionary. ${ }^{7}$ In this new social fabric, dominated by emotional factors, the face has a privileged status. I began this study with a long list of technological techniques for counterfeiting the face, but this is part of the overall ontological status of an online culture in which anything can potentially be counterfeited. "Trust is the new scarcity" claims one of the authors, trying to grasp today's essentials. ${ }^{8}$ We cannot but think of the times of the gold standard when the scarcity of gold was the main source of trust in the precious metal, necessary for the global financial system to stay stable. With its primordial and prereflexive potential to establish a relation of trust, in today's context the trustworthy face is the new gold. The success of the influencers' business is evidence that, notwithstanding the well-known practices of falsifying its digital appearance, the face's ontological statute is still based on the relation with an agency of trust.

\section{Trustworthy face as gold}

The face is the semiotic universe par excellence, where the equilibrium between nature and culture feeds the social fabric of every civilization in the most sublime way. Anatomically the same, the face has inspired a huge variety of myths, rituals, representations, businesses, etc. in different cultures (Leone 2019: 19-20). The digital globalization of the world is attributing a new, more unified, but still fundamental role to the face, where trust is the scarcest resource of the social fabric. We see this clearly with the crucial role of the face in the megatrend of the influencers' profession.

\footnotetext{
7 See https://languages.oup.com/word-of-the-year/2016/; last accessed on 31 January 2021.

8 McCullen, Aidan 2019. Why we need public broadcasters - Trust is the new scarcity. Medium, 7 March 2019, is available at https://medium.com/thethursdaythought/why-we-need-publicbroadcasters-trust-is-the-new-scarcity-65c32577e1cd; last accessed on 31 January 2021.
} 
The face of the professional influencer is monetized trust. In the same way, the money sign is trust inscribed. Faces are the new species of coins of the internet where their value is measured and expressed by the trustworthiness, inscribed on their "heads and tails". The extended neuroscientific research on the trustworthiness of the face suggests that there are objective methods of evaluating it. With the help of semiotics we may start work on a tool designed to elaborate a semiotic trust profile of the face, similar to the evaluation of the quality of gold before the coinage, by analogy with the existing tools for business organizations.

\section{Conclusion}

This is the first research paper which brings together face, trust and semiotics. As pairs, all three combinations - semiotics and face, semiotics and trust and face and trust - are well explored. My main contribution would be the opening of a new research direction, rich in theoretical potential and in operative application on a socio-economic megatrend in digital culture: namely studying the sphere of social media influencers. This is not the only cultural reality, envisaged by the research direction, but I think it is the most relevant one to start with. It is one which, after a certain number of contributions and after establishing a basic vocabulary, could be extended to other occurrences of the face in e-technological societies.

One of the major claims of the paper is that there can be no other approach to such complex object as the semiotics-face-trust interplay than an interdisciplinary one. Interdisciplinarity would include the economic logic of online communications, especially working on the differences between linear textual actualization and interactivity. The methodological perfection of the generative approach of the Paris School of semiotics is one of the major obstacles to opening the semiotic theory to interactive communication. The first step is the elaboration of a new model of the money sign, seen as trust inscribed, which would allow the semiotic modelling of digital interactivity.

At the same time, the advent of social media (Web 2.0) has brought about the full extent of the post-truth era. Trust has become one of the scarcest resources for our social fabric. In such a context, it has become obvious that appearance dominates over substance and face trustworthiness is increasingly playing a decisive role in the success of the new-economy ventures, consisting mainly of services and access to experiences. Trustworthy faces work like valuable currency in the trust-scarce economic context, comparable to the role of gold as a precious and scarce material for the finances during the gold standard. In support of such a parallel comes the evidence from neuro-sciences. It has been found that the 
trustworthiness of the face works on a primordial and pre-reflexive level, ascribing to it an absolute value in the establishment of the phatic function in online interaction.

\section{References}

Alexandrou, Alex; Maras, Marie-Helen 2018. Determining authenticity of video evidence in the age of artificial intelligence and in the wake of Deepfake videos. The International Journal of Evidence \& Proof 23(3): 255-262. https://doi.org/10.1177/1365712718807226

Bacharach, Michael O. L.; Gambetta, Diego 2001. Trust in signs. In: Cook, Karen S. (ed.), Trust in Society. New York: Russell Sage Foundation, 148-184.

Bankov, Kristian 2003. Face and understanding. In: Tarasti, Eero (ed.), Understanding/ Misunderstanding: Contributions to the Study on the Hermeneutics of Signs. (Acta Semiotica Fennica XVI.) Helsinki: International Semiotics Institute, 192-200.

Bankov, Kristian 2018. From text to interaction. Digital Age in Semiotics and Communication 1: 9-17. https://doi.org/10.33919/dasc.18.1.1

Bankov, Kristian 2022. The Digital Mind: Semiotic Explorations in Digital Culture. London, Cham: Springer Nature.

Barthes, Roland 1981. Camera Lucida: Reflections on Photography. New York: Hill and Wang.

Biglari, Amir 2011. Sémiotique et Pragmatique des Passions dans Les Contemplations de Victor Hugo. Lille thèses. Université de Limoges, Faculté des lettres et sciences humaines.

Bikoula, Ignace Gustave 2011. La valutazione e la prevenzione del rischio sistemico con gli strumenti della network alaysis. PhD dissertation. La Sapienza University of Rome, Faculty of Economics.

Colins, Peter 1998. Faces, trust and the amygdala. Trends in Cognitive Sciences 2(7): 238. https://doi.org/10.1016/S1364-6613(98)80016-8

Eco, Umberto 1994. The Role of the Reader: Explorations in the Semiotics of Texts. Bloomington: Indiana University Press.

Eco, Umberto 2000. Kant and the Platypus. London: Vintage.

Ferguson, Niall 2008. The Ascent of Money: A Financial History of the World. New York: Penguin.

Greimas, Algirdas Julien; Fontanille, Jacques 1991. Sémiotique des Passions: Des États de Choses aux États d'Âmes. Paris: Seuil.

Kahneman, Daniel 2003. Maps of bounded rationality: Psychology for behavioral economics. American Economic Review 93(5): 1449-1475. https://doi.org/10.1257/ 000282803322655392

Le Gall, Véronique; Langley, Ann 2015. An abductive approach to investigating trust development in strategic alliances. In: Fergus, Lyon; Möllering, Guido; Saunders, Mark N. K. (eds.), Handbook of Research Methods on Trust. Cheltenham, Northampton: Edward Elgar Publishing, 36-45. https://doi.org/10.4337/9781782547419.00012

Leone, Massimo 2019. The semiotics of the face in digital dating: A research direction. Digital Age in Semiotics and Communication 2: 18-40. https://doi.org/10.33919/ dasc.19.2.2 
Lewicki, Roy J.; Brinsfield, Chad 2011. Framing trust: Trust as a heuristic. In: Donohue, William Anthony; Rogan, Randall G.; Kaufman, Sanda (eds.), Framing Matters: Perspectives on Negotiation Research and Practice in Communication. New York: Peter Lang Publishing, 110-135.

Lewicki, Roy J.; Brinsfield, Chad 2015. Trust research: Measuring trust beliefs and behaviours. In: Fergus, Lyon; Möllering, Guido; Saunders, Mark N. K. (eds.), Handbook of Research Methods on Trust. Cheltenham, Northampton: Edward Elgar Publishing, 46-64. https://doi.org/10.4337/9781782547419.00013

Marôpo, Lidia; Jorge, Ana; Tomaz, Renata 2019. "I felt like I was really talking to you!": Intimacy and trust among teen vloggers and followers in Portugal and Brazil. Journal of Children and Media 14: 22-37. https://doi.org/10.1080/17482798.2019.1699589

Meyerson, Debra; Weick, Karl E.; Kramer, Roderick M. 1996. Swift trust and temporary groups. In: Kramer, Roderick M.; Tyler, Tom R. (eds.), Trust in Organizations. Thousand Oaks: Sage Publications, 166-195. https://doi.org/10.4135/9781452243610.n9

Pope, Michael 2018. Peircean faith: Perception, trust, and religious belief in the conduct of life. Transactions of the Charles S. Peirce Society 54(4): 457-482. https://doi.org/10.2979/ trancharpeirsoc.54.4.02

Shen, Cuihua; Kasra, Mona; Pan, Wenjing; Bassett, Grace A.; Malloch, Yining; O’Brian, James F. 2019. Fake images: The effects of source, intermediary, and digital media literacy on contextual assessment of image credibility online. New Media \& Society 21(2): 438-463. https://doi.org/10.1177/1461444818799526

Slepian, Michael L.; Ames, Daniel R. 2016. Internalized impressions: The link between apparent facial trustworthiness and deceptive behavior is mediated by targets' expectations of how they will be judged. Psychological Science 27: 282-288. https://doi.org/ $10.1177 / 0956797615594897$

Swedberg, Richard 2010. The structure of confidence and the collapse of Lehman Brothers. Research in the Sociology of Organizations 30: 71-114. https://doi.org/10.1108/S0733558X(2010)000030A007

Swedberg, Richard 2012. The role of confidence in finance. In: Cetina, Karin Knorr; Preda, Ales (eds.), Handbook of the Sociology of Finance. New York: Oxford University Press. https://doi.org/10.1093/oxfordhb/9780199590162.013.0028

Todorov, Alexander; Oosterhof, Nikolaas N.; Baron, Sean G. 2008. Evaluating face trustworthiness: A model-based approach. Social Cognitive and Affective Neuroscience 3: 119-127. https://doi.org/10.1093/scan/nsn009

\section{Лицо и доверие: семиотическое исследование инфлюенсеров, денег и миндалевидного тела}

В результате культурного взрыва Web 2.0 цифровая культура породила семиотический парадокс: с одной стороны, изображения лиц используются невероятно широко, с другой стороны, поводов усомниться в их подлинности всё больше. Это связано с тем, что графические технологии сделали сложные манипуляции с изображениями возможными, а также значительно их упростили. После обзора существующих семиотических моделей доверия я предлагаю новый подход, подчеркивающий ценностные свойства доверия по аналогии с денежным знаком, который по сути 
является «написанным доверием». Когнитивные исследования подтверждают гипотезу о том, что достоверность лиц оценивается нами неосознанно. Это означает, что заслуживающее доверия лицо является предпосылкой для более успешного общения, чем не заслуживающее доверия, независимо от темы разговора или культурного контекста. Пример влияния инфлюенсеров показывает, что в глобализирующейся культуре, в которой доминирует интернет, заслуживающие доверия лица обладают многосторонним коммуникативным преимуществом.

\section{Nägu ja usaldus: semiootiline sissevaade suunamudijatesse, rahasse ja mandeltuuma}

Pärast Web 2.0 kultuuriplahvatust on digikultuuris avaldunud ilmselt semiootline paradoks, mis on seotud nägude uskumatult laialt levinud kasutamisega, samas kui põhjus nende nägude autentsuse usaldamiseks on pidevalt kahanemas. Seda seetõttu, et graafiline tehnoloogia on muutnud keerukad pildimanipulatsioonid niihästi võimalikeks kui ka kergesti teostatavateks. Alustan ülevaatega usalduse olemasolevatest semiootilistest mudelitest ja sellega seotud kaalutlustest ning pakun seejärel välja uue lähenemise, mis rõhutab usaluse väärtustgenereerivaid omadusi analoogia põhjal raha märgiga, mida peetakse "kirja pandud usalduseks". Uurimistöö neuroteaduste valdkonnas toetab hüpoteesi, et näo usaldusväärsuse üle otsustatakse mõtlemiseelselt ja ürgselt. Nii tähendab see, et usaldusväärne nägu on eeldus edukamaks suhtlemiseks kui ebausaldusväärne, sõltumata aruteluobjektist ja kultuurikontekstist. Ühismeedia suunamudijaid puudutav näide demonstreerib, et globaliseeruvas kultuuris, kus domineerib internet, on usaldusväärne nägu mitmekülgseks eeliseks, millel on tuntav mõju. 